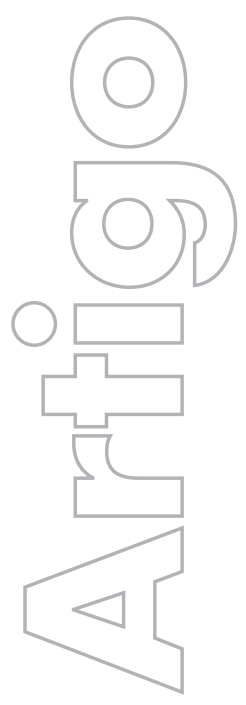

revista

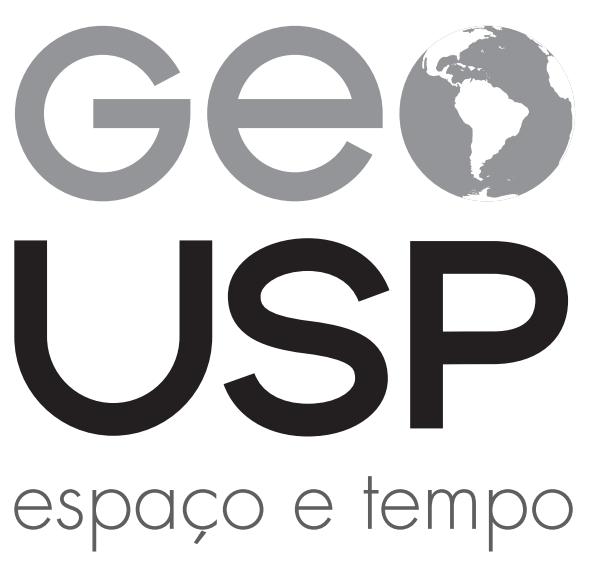

Volume $18 \cdot n^{\circ} 1(2014)$

\title{
Uma definição de meio ambiente
}

\section{Carlos Francisco Gerencsez Geraldino}

p. $403-415$

Artigo disponível em:

http://www.revistas.usp.br/geousp/article/view/84540

Como citar este artigo:

GERALDINO, C. F. G. Uma definição de meio ambiente. GEOUSP - Espaço e Tempo (Online), São Paulo, v. 18, n. 2, p. 403-415, 2014.

\section{$(\mathrm{cc}) \overline{\mathrm{EY}}$}

Este artigo está licenciado sob a Creative Commons Attribution 3.0 License. 


\title{
Uma definição de meio ambiente
}

Carlos Francisco Gerencsez Geraldino

\section{Resumo}

Trata-se de uma proposta de definição do conceito de meio ambiente a partir da compreensão das relações ambientais específicas mantidas entre os seres não-vivos, os seres vivos e os seres humanos.

Palavras-chave: Definição. Conceito. Meio ambiente.

\section{A definition of environment}

\begin{abstract}
This paper proposes to define the concept of environment from the understanding of specific environmental relations maintained among the non-living beings, living beings and human beings.
\end{abstract}

Keywords: Definition. Concept. Environment.

\section{Introdução}

$\bigcirc$ objetivo deste texto é responder sinteticamente à pergunta: $\bigcirc$ que é meio ambiente? Sem adentrar o campo da etimologia, tomando a expressão como equivalente de ambiente e meio, partiremos do pressuposto de que a essência do conceito deve ser inicialmente investigada sob dois aspectos: um negativo e outro positivo. Isso quer dizer que, ao questionar o que é o meio ambiente, devemos, antes de tudo, ter estabelecido a que coisa este se faz meio e, portanto, a que coisa ambienta. Afinal, como bem defendeu Richard Hartshorne (1978, p. 66), "o conceito de meio não tem sentido, exceto em referência àquilo que ele envolve"; ou, como quis Amos Rapoport (1978' apud Holzer, 1997, 80), tal conceito define-se basicamente por ser "qualquer condição ou influência situada fora do organismo, grupo ou sistema que se estuda". Então, só podemos começar dizer algo sobre o meio ambiente após termos afirmado outro ente ao qual este se faz como não sendo. Meio ambiente, assim, não pode ser compreendido como uma coisa entre coisas; algo que nos permita optar por começar a investigar seu ser positivamente, tal como podemos fazer com uma cadeira ou com um cachorro. Pois, por exemplo, na tentativa de dizer o que são

1 RAPOPORT, Amos. Aspectos humanos de la forma urbana. Barcelona: Gustavo Gilli, 1978. 
ambos, podemos começar nos referindo a eles por juízos positivos como "uma cadeira é algo feito para sentar" ou "o cachorro é um animal que late". Todavia, este procedimento não cabe à definição de meio ambiente. Para afirmar algo devemos antes tê-lo tratado negativamente. Ou seja, meio ambiente primeiro tem que não ser algo, para depois ser. Esta é sua elementar condição: a negativa. Embora que já nesta própria se assente, em concomitância, outra de igual valor: a relativa. Pois, ao dizermos "meio não é algo", estamos de forma implícita dizendo que meio é relativo a algo. Daí tudo aquilo que não é aquela(e) cadeira/cachorro, faz-se como ambiente daquela(e) cadeira/cachorro. Relatividade e negatividade fazem-se, portanto, como os princípios necessários para toda e qualquer tentativa de definição deste conceito.

Se para encontrarmos as propriedades do meio ambiente devemos antes afirmar as características do tipo de ser do qual se faz negativo e relativo, então, chegamos à necessidade de especificar de que tipo de ser falamos. Assim, observando o ambiente que nos cerca, que se estende dos papéis e canetas próximos à imensidão incógnita do universo, verificaremos uma pluralidade de seres dos quais vamos aqui distinguir agrupando-os em três tipos fundamentais, a saber: (i) seres inanimados ou não-vivos, (ii) seres vivos ou orgânicos, (iii) seres conscientes ou humanos. Esse deslindar tripartido é realizado a partir da aplicação de dois recortes arbitrários no real: o recorte da vida e o da consciência. Fazendo que tenhamos para analisar três tipos de meios com suas respectivas relações particulares: (i) o meio em que se encontram os seres não-vivos, (ii) o meio relativo aos seres vivos, (iii) e o meio ao qual ambienta os seres humanos. A seguir, detalhamos suas qualidades.

\section{O ambiente das coisas}

$\bigcirc$ ambiente relativo aos seres inanimados, não-vivos ou inorgânicos, age sobre eles deteriorando-os. A relação ser/meio, nesse caso, é constituída por uma via de mão única. Por exemplo, o ambiente ao qual se encontra certa pedra agirá sobre ela deteriorando-a, fazendo que, com o tempo, deixe de ser pedra para transforma-se em areia; ou melhor, fazendo com que deixemos de designá-la como sendo "pedra" para designá-la como "areia". $\bigcirc$ que faz a pedra ter certa permanência no ambiente é apenas sua específica durabilidade. A pedra, a caneta e a cadeira têm uma durabilidades diferentes; umas duram mais, outras menos. Mas o importante a considerar é o fato de absolutamente não agirem visando sua permanência. São o que são aos nossos olhos até suas formas diluírem-se em outras, motivando-nos a dar-lhes outros nomes como areia, lixo ou lenha. "Nada há de rígido nem imutável no desenho que a natureza põe ante nossos olhos", já dizia, à moda de Heráclito, Vidal de La Blache (1943, p. 20). E mesmo suas individualidades lhes são exteriores, pois só se individualizam como seres a partir de nosso julgamento; precisamente, de nossa análise. Assim, certa pedra só será certa pedra porque antes delimitamos sua forma, fazendo uso da categoria espaço, de outras coisas postas no ambiente. E tal pedra só ganha movimento do ser ao não-ser, da pedra à não-pedra, devido ao seu específico complemento de determinação dialética; fenômeno que, no caso, os geólogos chamariam de intemperismo. Portanto, o meio ambiente ao qual estão os seres inorgânicos incide sobre eles como uma força externa e contrária. 
Porém, devemos notar que o meio desses tipos de ser não se faz imanente a eles. A pedra não gera um ambiente, uma ambiência, ao seu arredor. Ela é pura indiferença ao meio. A relação pedra/meio só pode ser construída pela cognição de um terceiro que primeiro afirmou existir uma pedra e depois a alocou às determinações de um meio, relacionando ambos. É por essa razão que Richard Lewontin asseverou:

Assim como não pode haver organismo sem ambiente, não pode haver ambiente sem organismo. Há uma confusão entre a assertiva correta de que existe um mundo físico externo a um organismo que continuaria a existir na ausência da espécie e a afirmação incorreta de que os ambientes existem sem as espécies. [...] Deslizamentos de gelo, depósitos de cinza vulcânica e fontes de água não são ambientes. São condições físicas das quais ambientes podem ser construídos. Um ambiente é algo que envolve ou cerca, mas, para que haja envolvimento é preciso que haja algo no centro para ser envolvido (1998 apud Deus, 2007, p. 66).

Desse modo, o meio ambiente só aflora indubitavelmente e em todo o seu sentido quando dispomos do recorte da vida, fazendo o mundo deslindar-se entre seres inorgânicos/não-vivos e seres orgânicos/vivos. Mas aí surge a pergunto: o que, então, haveria de ser vida?

\section{O ambiente dos viventes}

De acordo com Richard Dawkins (200la), a vida é um acaso natural ocorrido na sopa originária dos oceanos primitivos da Terra, tendo se iniciado quando um microssistema organizado de moléculas - daí o porquê de a expressão organismo aparecer muitas vezes como sinônimo de ser vivo - logrou se duplicar. Posteriormente, tais moléculas autorreplicantes se utilizaram de outras proteínas para formar uma membrana que separou seu ambiente interno do ambiente externo. Essas "muralhas proteicas", que não são mais do que a forma corpórea dos seres, foram se diferenciando nos múltiplos caminhos conduzidos acidentalmente pela evolução natural. Dividindo-se em uma enormidade de espécies transformadas pela necessidade de se adaptarem à pluralidade de meios terrestres particulares. Assim, seguindo tal raciocínio, não nos equivocaríamos se constatássemos que a tênue e instável membrana iniciada nos primeiros seres vivos, hoje, mais de três bilhões de anos depois, está para nós como nosso próprio corpo; e que aquele mesmo princípio ocorrido há longínquos anos, a despeito que morte dos indivíduos possa vir a nos fazer pensar que a vida é fragmentada, ainda se mantém contínuo, tal como expressou François Jacob (1983, p. 99):

Cada corpo vivo, fruto de um grão ou de um feto, em outro momento fez parte de um corpo semelhante. Antes de adquirir autonomia, antes de tornar-se sede de uma vida independente, todo organismo primeiro participou da vida de outro ser de que depois se separou. A vida se transmite de ser para ser por uma sucessão ininterrupta. A vida é contínua.

2 LEWONTIN, Richard. A tripla hélice. São Paulo: Companhia das Letras, 1998. 
E aquilo que dá sequência à vida são as informações de autorreplicação contidas nos ácidos nucleicos, transmitidas de ser para ser, nomeadas por genes. Esses são os verdadeiros "mensageiros da vida". São eles que atiçam a matéria inerte a contrapor-se com o entorno, dando o sentido de organização necessário à constituição do ser vivo.

Jacques Monod (1971) argumentou que a diferença entre um ser não-vivo para o ser vivo reside na propriedade que o segundo tem de ser telenômico. Ou seja, enquanto o ser não-vivo absolutamente não age às intempéries do meio, deixando-se dissolver nelas, o ser vivo guarda um princípio de negação à negação exercida pelo meio, portanto, agindo frente a ele. Argumentando ainda que só se é possível entender a capacidade de ação quando consideramos a dimensão temporal - pois a ação apenas se dá quando o agente visa algum fim - o autor diz que os seres vivos são seres abertos ao futuro, enquanto os seres inertes padecem do passado. Concordando com isso, necessitamos apenas lembrar que o fim inscrito e programado nos genes dos viventes faz por ser único, a saber: a conservação da espécie. A despeito de como que estes seres vão obter isso - lançando mão de incríveis estratégias bélicas estudadas pelos biólogos - o fim do projeto de todo ser vivente é a sobrevivência da espécie; não necessariamente a do indivíduo, mas da informação contida em seus genes. Pois, enquanto que os indivíduos morrem, os genes sobrevivem e se aperfeiçoam tendendo sempre se manterem às intempéries singulares dos ambientes. Os genes, dir-nos-ia Dawkins (200lb), ditam os caminhos dos vivos. Nesse sentido, são ilustrativas as palavras de Samuel Butler (apud Brockman, 1988, p. 140): "A galinha é apenas o meio pelo qual o ovo produz outro ovo".

A vida, de tal modo, iniciou-se como um princípio de negação ao meio e se mantém na necessária e constante luta frente a ele. Nas palavras de Jacob (1983, p. 97): "O corpo vivo está sujeito à ação de influências variadas oriundas das coisas e dos seres e que tendem a destruí-lo. A vida é exatamente este princípio de luta contra a destruição". No entanto, devemos bem atentar para o fato que o tipo de relação do ser vivo para com o meio faz-se outra daquele do ser não-vivo. Tanto que já não podemos dizê-la apenas contrária, mas contraditória, pois o sentido da ação agora tem mão dupla. O que quer dizer que, ao mesmo tempo em que é negado pelo meio, o ser depende igualmente do meio para continuar a ser; em outras palavras, o meio nega e afirma o ser concomitantemente.

O meio, para o ser vivente, como afirmou José Ortega y Gasset (1963), faz-se como um composto fruto da somatória de adversidades e de possibilidades. E, diferente dos seres não-vivos, a relação com o meio faz-se como necessária aos seres viventes. Pois se a pedra continua a ser pedra quase que indiferente à configuração do meio em que está, já uma raposa ou uma bactéria, no entanto, necessitam estar em um meio bem mais específico para conseguirem sobreviver. Afinal, ambas, literalmente, só são na necessária relação com o meio. Nesse sentido, se a pedra ou um galho seco não geram uma ambiência, a raposa e a bactéria sim; para elas, o meio é imanente. $O$ vivente, portanto, suscita o meio.

Não bastasse isso, a contradição estabelecida não se encontra somente na relação para com o meio. O ser vivo resguarda dentro de si outro tipo de contradição de igual importância: a fisiológica. Pois, ao tempo em que precisa do seu corpo para ser, este mesmo corpo o faz concomitantemente deixar de ser. Essa é a contradição que faz com que já a partir do nasci- 
mento o vivente torne a ampulheta de sua morte. Sobre ela, disse Georg Hegel (1969³ apud Lefebvre, 1975, p. 193): "Uma coisa é viva tão-somente quando contiver em si a contradição, quando for essa coisa que apreende e conserva a contradição em si" . Portanto, da soma de dois tipos de contradição aflorar-se uma possível compreensão do que a vida é, a saber: algo só é vivo quando se encontra na dupla tensão de uma contradição externa, a mesológica, e de uma contradição interna, a fisiológica.

Contudo, tais explicações não seriam suficientes se quiséssemos compreender o sentido pleno do conceito meio, pois, como já havia salientado Max Sorre (1984, p. 89), "em se tratando do homem, a noção de meio se enriquece", graças a sua singular condição de ser. Mas o que nos faz diferentes dos demais seres com vida? Essa é uma pergunta fundamental para entendermos nossa específica relação para com o ambiente. No entanto, não poderíamos respondê-la interrompendo a cadeia lógica de explicação da vida, dada pela teoria evolucionista, com uma explicação de cunho especulativo ou metafísico. Mesmo bem sabendo, de início, que a biologia não basta para explicar o ser do homem, devemos procurá-lo partindo dela, pois ela é sua base original. A consciência, aquilo que nos distingue dos outros entes vivos, aflorou no homem devido a sua complexidade biológica centrada no que tange ao setor do aparelho nervoso central. Por isso é que podemos dizer que ela só poderia ter aparecido no homem, e não num esquilo ou num urso. Não que, todavia, os outros tipos de ser viventes não tenham posse de algo que podemos chamar de consciência, mas que o tipo de consciência do homem é de tal modo que o faz se diferenciar frente aos demais seres. Ela se fez fruto de um processo que os biólogos chamam de exaptação (Gould; Vrba, 1982), que diz que determinados ganhos evolutivos só podem se realizar dependendo do grau de complexidade em certos setores orgânicos que os corpos das espécies atingem. Porém, isso não quer dizer que o homem teve como destino ser portador de consciência; afinal, em absoluto, "a evolução não tem projeto" (Neves, 2006, p. 252). Mas sim, que por acaso ela apareceu, estabelecendo vantagens adaptativas, e se firmou depois como uma necessidade; resultando ao homem, hoje, ser um animal consciente. Todavia, o que é isto que se chama por consciência? Como e quanto surgiu no homem? Qual sua relação com a linguagem e com a cultura? E, principalmente, o que ela faz por distinguir o ambiente de qualquer vivente do específico humano?

\section{O ambiente dos humanos}

Segundo Walter Neves (2006), a origem do ser humano pode ser considerada sob duas maneiras não conflitantes. A primeira, ocorrida há 200 mil anos, na África, com o aparecimento dos primeiros hominídeos com estrutura esqueletal correlata à atual. E a segunda, há 45 mil anos, com a instauração do módulo simbólico em nosso cérebro, acarretando ao que se entende por comportamento humano moderno. Assim, materialmente datamos de cerca de 200 mil anos. Porém, a capacidade simbólica, aquilo que nos fez diferentes dos demais entes orgânicos, só surgiu mesmo há 45 mil anos; datação relativa às primeiras manifestações artísticas em forma de esculturas e pinturas parietais, de fósseis ritualmente enterrados, de vestígios de adornos corporais com marcas pessoais ou étnicas e do aumento

3 HEGEL, G. W. F. Wissenschaft der Logik. Hamburgo: Felix Meiner, 1969. 
abrupto do número de ferramentas especializadas feitas não mais apenas de pedras, mas com ossos, chifres e dentes. Tal explosão inventiva foi a principal responsável por termos conseguido deixar a África para nos espraiar pelos mais diversos rincões com agressivas condições ambientais do planeta.

Mas o que haveria de ser essa capacidade simbólica? Nada mais que capacidade de criar e trabalhar signos; e signo, como esclareceu Paulo Perdigão (1995, p. 79), "é um objeto presente que serve para designar outro objeto não presente". Ou seja, tal capacidade proporciona o descolamento das coisas presentes para uma esfera ideal, estabelecendo-se como uma mediação para com o meio ambiente imediato. Ela nos trouxe, segundo Robert Foley (1998), a disposição de encenar consequências imagéticas para as ações pretendidas sem o gasto energético ou os altos riscos envolvidos na realidade de fato. Para Richard Klein (2005, p. 226), essa esfera abriu-se como uma oficina em nossa cabeça, onde passamos a "criar modelos mentais e fazer perguntas do tipo 'e se?"'; dotando-nos da singular habilidade de inovar.

A instauração do módulo simbólico não só modificou nossa relação com o entorno, mas também implicou mudanças radicais no próprio processo da evolução natural, como mostra a seguinte passagem:

Somos, assim, a única criatura no planeta dotada de pensamento simbólico. Essa é, na verdade, nossa única "singularidade" não repartida com o resto do reino animal, ou pelo menos com parte dele. E não se trata de uma singularidade trivial, aquelas que caracterizam as demais linhagens evolutivas que existiram e que ainda existem no planeta. Pela primeira vez na história da evolução, a própria seleção natural fixou um mecanismo que pode produzir comportamentos mal-adaptativos [...]. A seleção natural fixou em nós uma entidade mental que escapou de seu julgo, pelo menos parcialmente. Uma entidade com vida própria, gerida majoritariamente por critérios arbitrários e não adaptativos. Por ditames abstratos e não racionais. Em qualquer outra espécie, uma entidade como essa a teria levado à extinção em poucas gerações, se não na primeira. Por alguma razão, em nós, essa mesma entidade deve ter conferido uma imensa vantagem adaptativa qualquer no contexto competitivo do Pleistoceno Superior, pelo menos suficiente para neutralizar nossas inúmeras decisões irracionais, baseadas em valores abstratos. Talvez tenhamos perdido em adaptação, mas ganhado em adaptabilidade (Neves, 2006, p. 280).

Perdemos em adaptação, pois deixamos de apenas ter comportamentos adaptativos ao meio; e ganhamos em adaptabilidade, por poder modificá-lo. Se antes o ambiente nos modificava, agora, então, nós também o modificamos. É como se houvéssemos tomado o cinzel das mãos da natureza para passar também a geografar o planeta. Afinal, lembrando Friedrich Engels (1979, p. 223), "toda a ação dos animais, obedecendo a um plano, não conseguiu imprimir na Terra o selo de sua vontade. Somente o homem foi capaz de fazer isso".

Dessa feita, o módulo simbólico fez com que os imperativos do meio fossem relidos a partir das significações que abstrata e arbitrariamente os delegamos. Assim, os ditames dos genes que ordenam as ações de todos os seres vivos foram apagados em nós. E os atos naturais 
de comer, de habitar e de se reproduzir passaram a ganhar um significado, um sentido; passaram a ganhar um porquê de ter que comer, de ter que habitar e de ter que se reproduzir. Aquilo tudo que os viventes fazem como compromissos banais às suas sobrevivências passou a ser problematizado no homem. Nossa sobrevivência, ao cabo desse salto evolutivo, passou a ser tutorada pela existência. Portanto, o ser humano deixou de ser apenas mais um animal entre outros quando passou a problematizar sobre o que é; tornando-se, por conseguinte, outro tipo de ser e vivenciando outro tipo de experiência para com o ambiente. A respeito dessa nova condição natural, Peter Sloterdijk (2000, p. 35) comentou:

$\bigcirc$ ser humano poderia até mesmo ser definido como criatura que fracassou em seu ser animal [Tiersein] em seu permanecer-animal [Tierbleiben]. Ao fracassar como animal, esse ser indeterminado tomba para fora de seu ambiente e com isso ganha o mundo no sentido ontológico. Esse vir-ao-mundo extático e essa "outorga" para o ser estão postas desde o berço para o ser humano como heranças históricas da espécie. [...] $\bigcirc$ homem é o produto de um hiper-nascimento que o faz do lactente [Säugling] um habitante do mundo [Weltling]. [...] Esse êxodo geraria apenas animais psicóticos se, com a chegada ao mundo, não se efetuasse ao mesmo tempo um movimento de entrada naquilo que Heidegger denominou "casa do ser". As linguagens tradicionais do gênero humano tornaram capaz de ser vivido o êxtase do estar-no-mundo, ao mostrar aos homens como esse estar no mundo pode ser ao mesmo tempo experimentado como estar-consigo-mesmo. Nessa medida, a clareira é um acontecimento nas fronteiras entre as histórias da natureza e da cultura, e ao chegar-ao-mundo o humano assume desde cedo os traços de um chegar-à-linguagem.

O homem se faz como um animal fracassado, falho, no sentido que suas ações já não se dão sem a problematização interna do porquê fazê-las. A natureza, os instintos, os genes não o comandam. Para qualquer outro vivente, os problemas de sua existência já estão dados pelo meio. Sobreviver é depender e enfrentar as determinações do meio. Satisfazendo temporariamente problemas como a fome, não lhe resta angústia alguma. $\bigcirc$ animal saciado inteira-se, preenche seu ser; aí, a ecologia impera e, por conseguinte, o explica. Para o homem, isso não funciona. Afinal, a fome, como ilustrou Ortega y Gasset (1963), não causou em Mahatma Gandhi uma reação direta em prol da alimentação, pois, segundo esse filósofo, não queremos estar no mundo, mas queremos bem estar no mundo. E esse bem estar é diferente de estar não por ser um estar melhorado, mas por ser um modo livre e arbitrariamente escolhido por nós de estar. Daí, por exemplo, o suicídio ser a resolução humana para um estar que não se considera estar bem, mesmo que esse estar cumpra condições adequadas de sobrevivência.

Em contraponto à inauguração dessa psicopatia, o módulo simbólico deu-nos a linguagem mais aperfeiçoada dos viventes. E foi através dela que resolvemos o impasse derivado da pergunta que incide em nosso ser. $\bigcirc$ não saber bem o que somos bradou-se quando reconhecemos essa falha nos outros. E daí pudemos, por meio da linguagem apurada, edificar coletivamente explicações metafísicas, cujas formas exemplares seriam as religiões, para justificar nossa estada na Terra. A linguagem nos fez, por meio de socialização simbólica, humanos em essência; foi o principal ganho evolutivo do fracasso humano em seu ser animal. Max Scheler 
(2008, p. 8) já havia dito que o homem é: "Um ser 'espiritual' [que] já não se encontra, pois, sujeito ao impulso e ao meio, mas está 'liberto do meio' e, como nos apraz dizer, 'aberto ao mundo': semelhante ser tem 'mundo". Ao abrirmos o "mundo" todo nosso entorno ganhou um sentido, um significado sustentado e perpassado pela linguagem.

A decorrência direta do surgimento do simbólico e da sua abertura ao ser mediado pela linguagem foi precisamente aquilo pelo que se entende por cultura; sobre ela, Stephen Jay Gould (1999, p. 346) explica que:

As sociedades humanas mudam por evolução cultural, e não como resultado de alterações biológicas. [...] A evolução biológica (darwiniana) continua em nossa espécie; mas seu ritmo, comparado com a evolução cultural, é tão desmesuradamente lento que sua influência sobre a história do Homo sapiens foi muito pequena. [...] A evolução cultural pode avançar com tanta rapidez porque opera, contrariamente à evolução biológica - de maneira "lamarckiana", através de herança de caracteres adquiridos. $\bigcirc$ que uma geração aprende é transmitido à seguinte através da escrita, da instrução, do ritual, da tradição e de um sem número de métodos que os seres humanos desenvolveram para assegurar a continuidade da cultura.

A cultura é o resguardo social do simbólico imaginado individualmente; é o arcabouço do saber-fazer; é o abrigo do ser dos entes; é o acolhimento de todos os saberes criados e experimentados individualmente perpassados pela linguagem àqueles que não os vivenciaram. Por meio dela, um conhecimento adquirido por tentativa e erro, a duras penas, pode ser facilmente transmitido numa rápida conversa ilustrativa. A título de exemplo, basta considerar que o fundamento da agricultura - singelo conhecimento que ignoramos por mais de $90 \%$ do tempo de nossa existência com espécie - hoje é corriqueiramente aprendido pelas crianças logo nas séries iniciais das escolas. A cultura faz-se, assim, como uma estratégia adaptativa humana que foge aos domínios da adaptação natural.

Todavia, se a cultura nos deu ganhos incomensuráveis de transformação da natureza, por outro turno, nos fez nascer como os seres mais incompletos entre os viventes. Diferente dos demais que se ajustam desde muito jovens ao ambiente, o homem tem o seu futuro sempre aberto. Essa ausência de especialização ao meio natural demanda o auxílio da determinação da sociedade, tornando a criatura humana, mais do que todas, dependente do meio social. $\bigcirc$ Homo sapiens deve aprender para ser humano; há uma dependência inscrita em nossos genes de havermos passado por um processo de aprendizado para conseguirmos sobreviver frente às dificuldades do ambiente. Essa dependência de ensinamento que alguns biólogos chamam de neotenia é uma estratégia fisiológica baseada no prolongamento da infância até as fases mais maduras dos indivíduos a fim de ampliar o aprendizado social.

Tais contingências evolutivas resultaram aos humanos uma implicação ontológica única, a saber: o ser humano é o único ser da natureza que tem uma falta de ser em seu ser; caracterizando-se pela singular contradição de ser e não-ser ao mesmo tempo. Nas palavras de Ortega y Gasset (1963, p. 39): "O homem é o que não é, mas que aspira ser. [...] Um ente cujo ser consiste, não no que já é, mas no que ainda não é, um ser que consiste em ainda não ser". 
Essa contradição deve-se à capacidade de autorreflexão. E tal tipo de capacidade surgiu em concomitância ao pensamento simbólico. Pois, somente com a possibilidade dada pela criação imagética, de pôr-se por um instante fora de si, é que podemos entender que uma determinada criatura possa chegar ao ato da reflexão, de ensimesmar-se. É como que se toda a engenharia desenvolvida ao longo de milhares de anos para a compreensão da lógica dos fenômenos naturais expostos no ambiente, tornasse cento e oitenta graus e incidisse abruptamente em nossa própria interioridade. Ato que pôs a pergunta, e em suspenso a resposta, de nosso próprio ser. Sobre isso, à maneira de Martin Heidegger, Jean-Paul Sartre (2005, p. 681) declarou: "Sou o ser que é como ser cujo ser está em questão em seu ser. E este "é de meu ser é como sendo presente e inapreensível". Ou seja, a partir do momento em que determinado ser pôde pôr seu próprio ser em questão, recaiu em sua definição uma indeterminação de ser. Não que ao perguntar-se por si, o ser fez-se esvanecer por inteiro - afinal, o homem é de alguma forma, tem um corpo, uma história etc. - mas, sim, que a dúvida de ser instalou uma impossibilidade presente de resposta plena ao que somos.

A incompletude do ser entranhada em nós pela dúvida existencial obriga-nos a transcender rumo à nós mesmos. Fazendo-nos ser aquilo que ainda não é; aquilo que virá a ser; um ser, então, eminentemente projetivo. E projetar, bem entendido, significa sair pelo intelecto rumo ao futuro imaginado, retomando onde estamos com os fins para o nosso ser ainda em mente. Projeto, então, é a mediação subjetiva entre dois momentos de objetividade; é o movimento que Sartre (1966, p. 124) posteriormente chamou de progressivo-regressivo, em suas palavras: "O movimento da compreensão é simultaneamente progressivo (em direção do resultado objetivo) e regressivo (remonto em direção da condição original)". E é a partir desse movimento de ir-e-vir que nosso meio ambiente torna-se meio para algum fim. Pois, tudo que nos envolve ganha sentido somente à luz do fim que projetamos ser. Fim, vale lembrar, que não aquele do qual Monod expôs, unicamente visando à sobrevivência; mas, fim livremente escolhido pelo indivíduo. $\bigcirc$ conceito de projeto, assim, se contrapõe ao de teleonomia, pois enquanto no segundo o animal lê seu ambiente com os óculos da fome, buscando apenas manter seu ser ao alimentar-se, no primeiro, a leitura do ambiente é sempre feita a partir do nosso querer vir a ser nunca preenchido. No dizer de Sartre: "Corremos rumo a nós mesmos, e somos, por tal razão, o ser que jamais se pode alcançar" (2005, p. 267). Nosso ambiente é lido através das respostas provisórias que damos ao nosso ser em questão. Assim, não o percebemos como uma somatória das coisas que nos envolvem; o percebemos, sim, sob a particularidade de nossas ações pretendidas. Como bem sintetizou Luciano Lima (2010, p. 171): "O meio é feito de coisas. Mas não é coisa. É o nexo racional que fazemos entre as coisas, para gerar um movimento criador".

De tal modo, se podemos falar de uma causalidade das ações humanas, essa, no entanto, não pode ser entendida como uma simples relação mecânica de causa e efeito, como o movimento de uma bola de bilhar derivado do choque de outra. $\bigcirc$ que causa qualquer ação humana não é a configuração a priori do meio em que se está, mas a maneira com que este é singularmente lido segundo as projeções de ser. Por isso, concordaremos mais uma vez com Sartre (2005, p. 700) ao dizer: "O meio só poderia agir sobre o sujeito na medida exata em que este o compreende, ou seja, em que este o transforma em situação". Daí, exemplificar: "Determinado rochedo, que demonstra profunda resistência se pretendo removê-lo, será, ao contrário, 
preciosa ajuda se quero escalá-lo para contemplar a paisagem" (Sartre, 2005, p. 593); todavia: "Para o advogado que permanece na cidade e defende uma causa, [...], o rochedo não é difícil nem fácil de escalar: está fundido na totalidade 'mundo', sem dela emergir de modo algum" (Sartre, 2005, p. 601-602). Portanto, o significado que damos ao rochedo é que lhe fará ser ora um empecilho, ora um recurso, ou mesmo um algo qualquer, do qual resguardamos absoluta indiferença. Logo, em relação a sua dimensionalidade temporal, a causa para o humano não vem do passado, como para todos os outros entes naturais, mas do futuro. $\bigcirc$ que queremos ser e as coisas que devemos fazer para tal arranjam o nosso ambiente transformando-o em uma situação vivida individualmente.

Se acharmos necessário diferenciar conceitualmente, como quisera fazer Luiz D’ Agostini (2002), podemos até dizer que o homem não vivencia propriamente um meio, mas sim um ambiente num determinado meio, pois está sempre ambicionando certas coisas desse meio, arranjando-o de maneira pessoal, de acordo com seus projetos do momento e de sua vida. Em termos gerais, diferentemente de muitos, D'Agostini não entende a expressão meio ambiente como pleonástica, tendo cada termo um significado próprio. Sua proposta é que o meio seja compreendido como a base material, sinônimo de lugar, donde estão contidos os sujeitos conscientes que gerarão, por conseguinte, o ambiente; de forma que o "meio é dado; o ambiente emerge" (D’Agostini, 2002, p. 148).

Portanto, a despeito de certa margem de escolha terminológica que se venha a fazer - nomeando-o ora por meio, ambiente, meio ambiente, situação, arredor, entorno ou circunstância - o importante a se considerar é que em sua definição resguarde um paradoxo, uma ambiguidade própria da condição humana. Tal singularidade é condição de sermos liberdades situadas. $\bigcirc$ que quer dizer que não estamos no mundo movidos pelos acasos de ordem natural; pois somos livres para programar nossas ações. Todavia, nossa liberdade não é fazer o que queremos - como sair voando -, mas fazer o que podemos fazer. É uma tensão gerada pelo que vamos fazer daquilo que fizeram de nós. A liberdade não está na possibilidade de escolha de nosso corpo, de nossa história, de nossa geografia etc., pois isso tudo são determinações objetivas dadas e necessárias. Somos livres, no entanto, pelo sentido que damos a esse conjunto de fatos que constituem o que teremos como nossa situação no mundo, nosso meio ambiente (Sartre, 2005).

Não obstante, atentemos: a liberdade não é uma indeterminação, liberdade também é um tipo de determinação, porém, uma determinação que vai do sujeito ao objeto e não uma determinação que vem do objeto ao sujeito como o quer o determinismo. Nesse aspecto, devemos concordar plenamente com Lewis Mumford (1958, p. 17), ao afirmar que: "A rota do homem em sua evolução parte [...] do externamente condicionado para o internamente condicionado". Assim, ao fazermos necessárias escolhas de ação frente ao meio, nós nos determinamos como sujeitos; ou seja, como seres agentes. Livremente podemos escolher nossas ações, mas logo após a escolha, somos determinados por ela própria. Vamos atrás de um fim, um possível, que traçamos como realizável nas condições de nosso entorno. Sempre, entretanto, livres para estagnar essa ação planejada e reconfigurar os planos, determinando-nos novamente. E só entendendo que a liberdade é também uma determinação é que podemos estudar cientificamente o ser humano frente às suas ações para com o meio. 
Podemos entender o ser humano como materialidade forjada por processos físico-químico-biológicos, nas diversas configurações geográficas às quais se aventurou após deixar seu berço africano; buscando, desse modo, as determinações geográficas no sentido de síntese de múltiplas determinações relativas às especificidades dos lugares. Entendendo-o se negro, branco, loiro, moreno, ruivo, pequeno, longilíneo, como resposta da adaptação fisiológica ao meio. Buscando, desse modo, apreender como a geografia o determinou como materialidade. Mas também podemos entendê-lo como descritor e agente do meio geográfico. E aí teremos que vê-lo em sua liberdade. Entretanto, como poderemos pesquisar e analisar cientificamente a liberdade - e, consequentemente, o ser humano -, se esta é a antítese da determinação, que por sua vez é a necessidade de se fazer ciência? Essa pergunta não teria uma resposta satisfatória se nos fixássemos no conceito de liberdade como ausência de determinação ou brecha momentânea dessa, como o quer o senso comum, ou como o quis aquilo pelo que se consagrou por possibilismo na história do pensamento geográfico. Contudo, é compreendendo que liberdade não é uma indeterminação, mas uma determinação por parte do sujeito, é que resolvemos a questão corrigindo-a em suas premissas. $\bigcirc$ ser humano é livre por essência, em verdade, não tem essência a priori, por isso é livre. No entanto, "[...] não é livre para não escolher-se" (Sartre, 2005, p. 525); é escravo de sua liberdade. Assim, é obrigado a engajar-se no mundo. E, devido a essa necessidade geográfica, é que é obrigado a se determinar como ser. Escolhendo e projetando caminhos para realizar, determinando-se no mundo. Afinal, para o homem, "existir e situar-se constituem a mesma coisa" (Sartre, 2005, p. 392). E é precisamente isso que dá a possibilidade às ciências humanas fazerem-se como ciência dos homens, porque há uma determinação. Certamente, este é um objeto muito mais fugidio que outros, posto que o humano é livre para mudar a qualquer momento suas determinações, mas, obrigado a escolher-se, não pode ser sem se autodeterminar. Assim, a busca do entendimento de uma geografia como descrição da superfície terrestre passa por compreendermos as autodeterminações dos sujeitos, bem como, dos sentidos que atribuem aos seus respectivos meios, à sua situação no mundo.

Mas, meio ambiente, realidade e consciência, então, fazem-se como a mesma coisa? De certa maneira, sim. Pois, jamais conseguíramos afirmar a existência de um elemento desta tríade sem obrigatoriamente remetê-lo aos demais. Entretanto, não deveríamos deixar de nos ater a eles, fazendo por se diluírem num caldo indiscernível. A presença desses três nomes para um único fenômeno não é um capricho da ordem dos sinônimos, mas uma demonstração dos ganhos do pensamento analítico. É o olhar aguçado para um fenômeno complexo e estruturante que constitui a presença do mundo para nós. Daí três nomes que separam algo, que se de fato for separado, deixa de existir. Estes nos servem como ferramentas de elucidação teórica de um fenômeno, quando em ato, indiferenciável. Dessa forma, podemos dizer, em síntese, que meio ambiente e consciência são as faces de uma moeda chamada realidade.

\section{Conclusão}

$\mathrm{Na}$ busca de uma definição para meio ambiente, podemos começar dizendo que esse conceito é algo negativo e relativo a determinado ser, e, por conta disso, só podemos investigá-lo a partir do posicionamento prévio desse ser. Assim, aplicando dois recortes arbitrários ao real - o da vida e o da consciência -, chegaremos ao deslindar tripartido entre seres não vivos, seres vivos e seres conscientes, cada qual com constrangimentos específicos a sua permanência, como sintetiza o seguinte quadro: 


\section{Quadro 1}

Relação entre forças adversas e tipos de ser

\begin{tabular}{c|c|c|c}
\hline & não vivo & vivo & consciente \\
\hline mesológica & contrária & contraditória & contraditória \\
\hline fisiológica & - & contraditória & contraditória \\
\hline ontológica & - & - & contraditória \\
\hline
\end{tabular}

Vemos que, da passagem do ser inorgânico ao ser orgânico-consciente, temos a somatória pontual de três forças contrárias: a mesológica, a fisiológica e a ontológica. A primeira, a do meio, abrange tudo que existe materialmente na natureza. Faz-se como o próprio motor da dialética da natureza, do movimento das formas; tudo que existe está fadado a transformar-se, deixando de ser algo para ser não-algo que, por sua vez, far-se-á um novo algo. A segunda reduz imensamente a abrangência dos entes naturais, aplicando-se apenas àqueles que guardam vida em seu corpo; é a responsável pelo envelhecimento e pela morte. Já a terceira é a contradição instaurada na própria fundamentação do ser, fazendo com que, ao tempo em que um ser seja, não consiga se firmar plenamente como tal, devido à sempre presente dúvida sobre o que é. Como dito, essas contradições se formam como uma somatória. Assim, por exemplo, na pedra, incide a primeira apenas como força contrária, não contraditória, pois a pedra não precisa se relacionar com o meio para manter-se; na bactéria e no macaco, incidem a primeira e a segunda, ambas contraditórias; e, no ser humano, incide a soma das três, todas contraditórias.

O homem, portanto, enfrenta ao longo de sua vida três negações concomitantes de seu ser: a ambiental, fisiológica e a existencial. Faz-se como um ser bio-ontológico, como bem o definiu Elvio Martins (2007); bio, pois abrange em sua materialidade as duas contradições primeiras, a do meio e a do corpo; e ontológico, pois se individualiza a partir da escolha de seu ser no mundo, prevalecendo tal escolha na leitura singular que faz de seu ambiente.

Há no ser humano uma irredutibilidade ao meio. Ou seja, ao homem, não se pode dizer plenamente "diz-me onde estás e dir-te-ei quem és", pois isso é ecologia, e não se aplica ao animal tombado dessa esfera. Portanto, se de fato quisermos compreender o meio ambiente no qual se encontra um indivíduo ou um grupo, devemos antes questionar suas projeções de ser; devemos tentar compreender o ir ao futuro que elegeu(ram) como fim possível/faltante e retornar ao presente, captando neste os entraves e caminhos que devrá(ão) transpor e seguir para alcançá-lo(s).

\section{Referências}

BROCKMAN, J. Lamarck vive. In: Einstein, Gertrude Stein, Wittgenstein e Frankenstein. Trad. Valter Ponte. São Paulo: Companhia das Letras, 1988. p. 136-142.

D'AGOSTINI, L. A insuficiência do conceito de ambiente em meios onde o meio é ambiente. Geosul: Florianópolis, v. 17, n. 34, p.147-154, 2002.

DAWKINS, R. O relojoeiro cego. São Paulo: Companhia das Letras, 2001 la. . O gene egoísta. Belo Horizonte: Itatiaia, $200 \mathrm{lb}$. 
DEUS, E. Antropologia e ambiente. Dissertação (Mestrado em Antropologia) - Departamento de Antropologia, Universidade de Brasília, Brasilia, 2007.

ENGELS, F. A dialética da natureza. 3. ed. Rio de Janeiro: Paz e Terra, 1979.

FOLEY, R. Os humanos antes da humanidade. Trad. Patrícia Zimbres. São Paulo: Uniesp, 1998.

GOULD, S. J. A falsa medida do homem. Trad. Valter Siqueira. 2. ed. São Paulo: Martins Fontes, 1999.

; VRBA, E. S. Exaptation: a missing term in the science of form. Paleobiology, n. 8, p. 4-15, 1982 .

HARTSHORNE, R. Propósitos e natureza da geografia. 2. ed. Trad. Thomaz N. Neto. São Paulo: Hucitec, 1978.

HOLZER, W. Uma discussão fenomenológica sobre os conceitos de paisagem, lugar, território e meio ambiente. Território, ano II, n. 3, p. 77-85, 1997.

JACOB, F. Lógica da vida. Rio de Janeiro: Graal, 1983.

KLEIN, R. O despertar da cultura. Rio de Janeiro: Jorge Zahar, 2005.

LEFEBVRE, H. Lógica formal lógica dialética. Trad. Carlos Coutinho. Rio de Janeiro: Civilização Brasileira, 1975.

LIMA, L. O sentido é o meio. In: PONTUSCHKA, N.; OLIVEIRA, A. (Orgs.). Geografia em perspectiva. São Paulo: Contexto, 2010. p. 168-172.

MARTINS, E. Geografia e ontologia: o fundamento geográfico do ser. Geousp, São Paulo, n. 22, p. 33-51, 2007.

MONOD, J. O acaso e a necessidade. Trad. Alice Sampaio. Petrópolis: Vozes, 1971.

MUMFORD, L. A condição de homem. Trad. V. Reis. 2. ed. Porto Alegre: Globo, 1958.

NEVES, W. E no princípio... era o macaco! Estudos avançados, São Paulo, v. 20, n. 58, p. 249285, 2006.

ORTEGA Y GASSET, J. Meditação da técnica. Trad. e prólogo de L. W. Vita. Rio de Janeiro: Livro Ibero-Americano, 1963.

PERDIGÃO, P. Liberdade e existência. Porto Alegre: LEPM, 1995.

SARTRE, J.-P. O ser e o nada. Trad. Paulo Perdigão. 13. ed. Petrópolis: Vozes, 2005. - Questão de método. Trad. Bento Prado Jr. São Paulo: Difusão Europeia do Livro, 1966.

SCHELER, M. A situação do homem no cosmos. Trad. Arthur Morão. Lisboa: Texto E Grafia, 2008.

SLOTERDIJK, P. Regras para o parque humano. Trad. José Marques. São Paulo: Estação Liberdade, 2000.

SORRE, M. A noção de gênero de vida e sua evolução. In: MEGALR, J. (Org.). Geografia. Trad. Januário Megale, Maria França e Moacyr Marques. São Paulo: Ática, 1984.

VIDAL DE LA BLACHE, P. A geografia na escola primária. Trad. Angel Rêgo. Boletim Geográfico, Rio de Janeiro, ano I, n. 1, p. 16-23, 1943. 